University of Nebraska - Lincoln

DigitalCommons@University of Nebraska - Lincoln

\title{
Nutrient Uptake of Maize Affected by Nitrogen and Potassium Fertility in a Humid Subtropical Environment
}

H. Arnold Bruns

USDA-ARS, abruns@ars.usda.gov

M. Wayne Ebelhar

Mississippi State University

Follow this and additional works at: https://digitalcommons.unl.edu/usdaarsfacpub

Part of the Agricultural Science Commons

Bruns, H. Arnold and Ebelhar, M. Wayne, "Nutrient Uptake of Maize Affected by Nitrogen and Potassium Fertility in a Humid Subtropical Environment" (2006). Publications from USDA-ARS / UNL Faculty. 523. https://digitalcommons.unl.edu/usdaarsfacpub/523

This Article is brought to you for free and open access by the U.S. Department of Agriculture: Agricultural Research Service, Lincoln, Nebraska at DigitalCommons@University of Nebraska - Lincoln. It has been accepted for inclusion in Publications from USDA-ARS / UNL Faculty by an authorized administrator of DigitalCommons@University of Nebraska - Lincoln. 


\title{
Nutrient Uptake of Maize Affected by Nitrogen and Potassium Fertility in a Humid Subtropical Environment
}

\author{
H. Arnold Bruns \\ USDA-ARS, Crop Genetics and Production Research Unit, \\ Stoneville, MS, USA \\ M. Wayne Ebelhar \\ Mississippi State University, Delta Research and Extension Center, \\ Stoneville, MS, USA
}

\begin{abstract}
Nitrogen (N) and potassium (K) fertility management of maize (Zea mays L.) in the humid subtropical Mississippi Delta may differ from a temperate climate because of its use in rotation with cotton (Gossypium hirsutum L.), soil temperatures rarely falling to $0^{\circ} \mathrm{C}$, and heavy winter rains that facilitate nutrient losses. An experiment to determine the $[\mathrm{N}]$ (concentration $=[]$ ), phosphorus $[\mathrm{P}],[\mathrm{K}]$, calcium $[\mathrm{Ca}]$, magnesium $[\mathrm{Mg}]$, iron $[\mathrm{Fe}]$, manganese $[\mathrm{Mn}]$, zinc $[\mathrm{Zn}]$, and copper $[\mathrm{Cu}]$ and their total contents plant ${ }^{-1}$ of maize grown in rotation with cotton, using $\mathrm{N}$ fertility levels of $\left(134,179,224,269\right.$, and $\left.314 \mathrm{~kg} \mathrm{Nha}^{-1}\right)$ in combination with $\mathrm{K}$ fertility levels of $\left(0,45,90\right.$, and $\left.134 \mathrm{~kg} \mathrm{Kha}^{-1}\right)$ was conducted in 2000 and 2001 at Tribbett, MS. Ear leaves, immature ears, and husks collected at growth stage R2 and grain and stover collected 21 days after R6 were dried, weighed, and analyzed for nutrient concentration. Plots were also harvested for yield, kernel weight, grain bulk density, and harvest index (HI). Increased [N] values of about $1.3 \mathrm{mg} \mathrm{g}^{-1}$ occurred in all organs except the stover between 134 and $314 \mathrm{~kg} \mathrm{Nha}^{-1} \mathrm{~N}$ fertility. Stover $[\mathrm{N}]$ increased approximately $3.0 \mathrm{mg} \mathrm{g}^{-1}$ within the same $\mathrm{N}$ fertility range. Total $\mathrm{N}$ content of ear leaves, grain, and stover increased by about $11.0,550.0$, and $730.0 \mathrm{mg} \mathrm{plant}^{-1}$, respectively, with $\mathrm{N}$ fertility increased from 134 to $314 \mathrm{~kg} \mathrm{Nha}^{-1}$. Yields, kernel weights, grain bulk densities, and harvest indices also increased with added $\mathrm{N}$ fertility. Several micronutrient concentrations and contents increased as $\mathrm{N}$ fertility increased.
\end{abstract}

Received 8 August 2004, Accepted 10 May 2005

Address correspondence to H. Arnold Bruns, USDA-ARS, Crop Genetics and Production Research Unit, Box 345, Stoneville, MS 38776, USA. E-mail: abruns@ars. usda.gov 
Increased $\mathrm{K}$ fertility had only limited influence on concentrations of most nutrient elements. The nutrient contents of most elements in the stover increased with added $\mathrm{K}$ fertility compared with plots that received no supplemental $\mathrm{K}$ fertilizer. These data showed between 139 and $265 \mathrm{~kg} \mathrm{Nha}^{-1}$ was permanently removed by grain harvest and suggest that $\mathrm{N}$ fertility recommendations for the Mississippi Delta may be low for maize yield goals above $10 \mathrm{Mg} \mathrm{ha}^{-1}$. Added $\mathrm{K}$ fertilizer has minimal benefit to maize when soil test levels are adequate but are important to succeeding cotton crops where $\mathrm{K}$ uptake during fruiting can exceed the soil's ability to release $\mathrm{K}$ for uptake.

Keywords: Crop rotations, cotton, irrigation

\section{INTRODUCTION}

Maize production in the Mississippi Delta has more than doubled in the past decade from 161,000 ha grown in Arkansas, Louisiana, and Mississippi in 1990 to 382,500 ha in the same region in 2000 . Average grain yields for the region have also increased from 6.0 to $8.1 \mathrm{Mg} \mathrm{ha}^{-1}$ for the same period (NASS-USDA 2001). Extensive use of maize in rotation with cotton, greater demand for locally grown grain by poultry and commercial channel catfish [Ictalurus punctatus (Rafinesque)] producers, and changes in government farm programs have contributed to the increase in maize production for the Mississippi Delta.

Nitrogen has long been considered the most influential macronutrient for maize grain yields. It is a key component of enzymes and other proteins essential to all growth functions. Benefits of $\mathrm{N}$ fertilization toward increasing grain yields in maize have been extensively documented (Barber 1976; Hageman 1979). Barber and Olson (1968) determined that maize yielding $9.5 \mathrm{Mg} \mathrm{ha}^{-1}$ of grain contained $191 \mathrm{~kg} \mathrm{Nha}^{-1}$ in all above ground tissue.

Management of $\mathrm{N}$ fertility in a humid subtropical environment such as the Mississippi Delta presents challenges different from those found in the U.S. Corn Belt. Soil-based N transformations that lead to both nitrification and denitrification occur throughout the year in a humid subtropical environment due to soil temperatures never falling below $0^{\circ} \mathrm{C}$. Winters in a humid subtropical environment often have frequent heavy rains that can leach soil $\mathrm{N}$ beyond the root zone of maize. This results in little to no $\mathrm{N}$ carryover from one growing season to the next. In Mississippi in 1961, it was recommended not to exceed $135 \mathrm{~kg} \mathrm{Nha}^{-1}$ for maximum grain yields of about $5.0 \mathrm{Mg} \mathrm{ha}^{-1}$ (Grissom and Spurgeon 1961). Current $\mathrm{N}$ fertility recommendations for maize in Mississippi are $23.2 \mathrm{~kg} \mathrm{Nha}^{-1}$ for each $\mathrm{Mgha}^{-1}$ of yield goal up to $6.3 \mathrm{Mgha}^{-1}$ and then $30.2 \mathrm{~kg} \mathrm{~N} \mathrm{ha}^{-1}$ for each additional $\mathrm{Mg} \mathrm{ha}^{-1}$ yield goal (Larson and Oldham 2003).

Potassium is the primary cation found in plants. Although it is not incorporated into any specific tissue, it serves several vital functions in plant growth and is required in large quantities by maize. Among these roles are neutralizing of organic acids formed during metabolism, enzyme activation, regulating leaf stomatal movement, and facilitating of photosynthate translocation 
(Streeter and Barta 1984). For cotton, K levels in the soil need to be plentiful at the beginning of the growing season. Potassium is vital for early reproductive growth, reductions in some diseases, and development of high quality fiber (Tupper et al. 1996; Minton and Ebelhar 1991; Kerby and Adams 1985). Potassium is subject to leaching during winter rains from some of the sandier soils of the Mississippi Delta used to grow maize and cotton (Larson and Oldham 2003).

Use of $\mathrm{NH}_{4} \mathrm{NO}_{3}$ and $\mathrm{NH}_{3}$ as a fertilizer is known to acidify soil and thus affect the availability of other cations (Gardner et al. 1985). Nutrient elements can interact with other elements and soil $\mathrm{pH}$ to diminish their availability or, in the case of some micronutrients, enhance their solubility in the soil solution to toxic levels. Tisdale and Nelson (1975) state that the absolute level of micronutrients in the soil may not be as important in plant growth as the amount of elements in relation to one another.

Commercial maize breeders have concentrated their efforts on increased grain yield and hybrid turnover is driven by improved yield performance more than any other factor (Duvick and Cassman 1999). Over the past 30 years, hybrid maize cultivars have been improved in plant architecture to increase canopy light interception and thus photosynthesis per unit of land area. Improvements have also been made in drought stress tolerance and tolerance of higher plant populations. Fertility requirements, particularly N, have increased for newer hybrids due to these changes. Information about the effects of $\mathrm{K}$ fertility on newer hybrids is limited.

The same planters and tillage equipment used to produce cotton in the Mississippi Delta is used to produce maize. Cotton production is constrained to row spacings of $76-102 \mathrm{~cm}$ by harvesting equipment, with most growers choosing wide row spacings. Maize and cotton crop rotations are popular in the Mississippi Delta. This experiment was conducted to examine the effects of different $\mathrm{N}$ and $\mathrm{K}$ fertility rates on yield, kernel weight, grain bulk density, harvest index (HI), nutrient concentrations, and nutrient contents of specific plant tissues during early reproductive growth and maturity of irrigated maize following cotton. These data can be helpful in developing nutrient management plans for maize in rotation with cotton in a humid subtropical environment.

\section{MATERIALS AND METHODS}

The experiment was conducted during the 2000 and 2001 growing seasons at Mississippi State University's Delta Branch Experiment Station's, Tribbett Satellite Farm near Tribbett, MS. Soil at the experimental site was a Forestdale/Dundee silty clay loam (Typic ochraqualfs/Aeric ochraqualfs). The experimental design was a randomized complete block replicated four times. Individual plots were four rows $27 \mathrm{~m}$ long and spaced $102 \mathrm{~cm}$ apart. Treatments were a $5 \times 4$ factorial arrangement of $\mathrm{N}$ fertility rates of 134 , $179,224,269$, or $314 \mathrm{~kg} \mathrm{Nha}^{-1}$ and $\mathrm{K}$ fertility rates of $0,45,90$, or 
$134 \mathrm{~kg} \mathrm{Kha}^{-1}$ within each block. The 20 treatments in each block were maintained in the same location for subsequent cotton crops. The previous crop each year was cotton. A uniform application of $134 \mathrm{~kg} \mathrm{Nha}^{-1}$ as a urea- $\mathrm{NH}_{4} \mathrm{NO}_{3}$ solution was applied prior to planting. Additional $\mathrm{N}$ fertility was applied as a sidedress at growth stage V6 as defined by Ritchie et al. (1997). Potassium fertility treatments were applied as a 0-0-16 solution sidedressed at growth stage V5. The maize hybrid Pioneer brand cv. 3223 was used in 2000 and planted on 7 March at a rate of 77,000 plants ha $^{-1}$ with an expected final plant population of about 70,000 plants ha $^{-1}$. In 2001, because of lower than expected yields in 2000, Pioneer ${ }^{1}$ brand cv. 31G98 was selected and planted 21 March at a rate of 86,000 plants ha $^{-1}$ with an expected final plant population of 78,500 plants ha ${ }^{-1}$. Plots were furrow irrigated when tensiometer readings of $-0.5 \mathrm{Mpa}$ at $0.5 \mathrm{~m}$ soil depth were noted. Irrigation commenced at growth stage R1 (silking) and continued until growth stage R6 (physiological maturity).

Ears and their subtending leaves from four randomly selected plants were harvested from each plot at growth stage R2. Leaves, husks, and immature ears were separated, oven dried at $70^{\circ} \mathrm{C}$, weighed, and ground to pass a 2-mm screen for later nutrient analyses. Approximately 21 days after growth stage R6, four different plants from each plot were harvested at soil level. Harvested material was placed in $28-\mathrm{kg}$ (25-pound) mesh bags, dried at $70^{\circ} \mathrm{C}$, and weighed. Ears were removed, grain separated from the ear, and weighed. Harvest indices (HI) as defined by Rassmusson and Gengenbach (1984), were calculated from these data. A 250-g sample of grain and a 1-kg sample of stover (leaf, stem, tassel, husk, and cob) were collected for nutrient analyses and ground to pass a 2-mm screen.

Nutrient analyses were conducted on the ground material at the Mississippi State University Extension Service Soil Testing and Plant Analysis Laboratory at Mississippi State, MS. Nitrogen concentrations were determined by using Ranker Semi-micro-Kjeldahl (AOAC 1975) and the remaining elements, $\mathrm{P}, \mathrm{K}, \mathrm{Ca}, \mathrm{Mg}, \mathrm{Zn}, \mathrm{Cu}, \mathrm{Fe}$, and $\mathrm{Mn}$ were quantified by using procedures outlined by Steckel and Flannery (1971).

Grain from the two center rows of each plot was machine-harvested and weighed. Grain samples were taken for moisture content and bulk density determinations. Grain yields were adjusted to $155 \mathrm{~g} \mathrm{~kg}^{-1}$ moisture content. Statistical analyses were conducted on data by using procedures outlined by McIntosh (1983) for combining experiments and PROC MIXED of the Statistical Analysis System (SAS Institute 2001).

\section{RESULTS AND DISCUSSION}

\section{Grain Yields and Agronomics}

Grain yields were greater in 2001 than $2000\left(13.6 \mathrm{Mg} \mathrm{ha}^{-1}\right.$ vs. $\left.8.8 \mathrm{Mg} \mathrm{ha}^{-1}\right)$. This was due primarily to a significantly $(p \leq 0.01)$ greater plant population in 
$2001\left(78,500\right.$ plants ha $\left.^{-1}\right)$ than in $2000\left(68,000\right.$ plants ha $\left.^{-1}\right)$. Increases in $\mathrm{N}$ fertility tended to increase grain yield, especially in 2001 (Table 1). Grain yields at $179 \mathrm{~kg} \mathrm{Nha}^{-1}$ were significantly $(p \leq 0.01)$ greater than the $134 \mathrm{~kg} \mathrm{~N}^{-1} \mathrm{~N}$ fertility rate in both 2000 and 2001 . However, no significant differences were observed in grain yields between 179 and $314 \mathrm{~kg} \mathrm{~N} \mathrm{ha}^{-1}$ in 2000 . In 2001, significant $(p \leq 0.01)$ yield increases were observed between 179 and 224 and between 224 and $269 \mathrm{~kg} \mathrm{Nha}^{-1}$.

Kernel weights increased as $\mathrm{N}$ fertility rates increased during both years of the experiment (Table 1). In 2000, kernel weight of maize grain grown with $134 \mathrm{~kg} \mathrm{Nha}^{-1}$ was significantly $(p \leq 0.01)$ less than all other $\mathrm{N}$ fertility treatments. No other significant differences in kernel weights were observed that year. By contrast, in 2001, kernel weights from plots receiving $224 \mathrm{~kg} \mathrm{~N} \mathrm{ha}^{-1}$ were significantly $(p \leq 0.01)$ greater than those receiving less $\mathrm{N}$. Kernels from plots receiving 269 and $314 \mathrm{~kg} \mathrm{Nha}^{-1}$ were heavier than grain from all other $\mathrm{N}$ fertility treatments. Grain bulk density also tended to increase with increasing $\mathrm{N}$ fertility rates in 2001, whereas no differences were observed among $\mathrm{N}$ fertility treatments in 2000 (Table 1). These factors also contributed to differences in yield observed between 2000 and 2001.

Harvest indices were significantly $(p \leq 0.01)$ greater at $224 \mathrm{~kg} \mathrm{Nha}^{-1}$ fertility level and above than for $179 \mathrm{~kg} \mathrm{Nha}^{-1}$, which was greater than the $\mathrm{HI}$ at $134 \mathrm{~kg} \mathrm{Nha}^{-1}$ level (Table 1). No effect on HI was observed among different rates of $\mathrm{K}$ fertility used in the experiment, nor was any significant interaction for $\mathrm{HI}$ noted between $\mathrm{N}$ and $\mathrm{K}$ fertility levels. Increased HIs observed at the greater $\mathrm{N}$ fertility rates indicate $\mathrm{N}$ facilitates translocation of photosynthate to developing maize kernels. Abundant levels of $\mathrm{N}$ in the soil

Table 1. Yield, kernel weight, grain bulk density, and harvest index of irrigated maize grown at Tribbett, MS in 2000 and 2001 with different levels of $\mathrm{N}$ fertility and following $\operatorname{cotton}^{a}$

\begin{tabular}{|c|c|c|c|c|c|c|c|}
\hline \multirow{2}{*}{$\begin{array}{l}\mathrm{N} \text { fertility } \\
\left(\mathrm{kg} \mathrm{Nha}^{-1}\right)\end{array}$} & \multicolumn{2}{|c|}{$\begin{array}{c}\text { Yield } \\
\left(\mathrm{Mg} \mathrm{ha}^{-1}\right)\end{array}$} & \multicolumn{2}{|c|}{$\begin{array}{l}\text { Kernel wt. } \\
\quad(\mathrm{mg})\end{array}$} & \multicolumn{2}{|c|}{$\begin{array}{l}\text { Bulk density } \\
\left(\mathrm{kg} \mathrm{m}^{-3}\right)\end{array}$} & \multirow{2}{*}{$\begin{array}{l}\text { Harvest } \\
\text { index }^{b}\end{array}$} \\
\hline & 2000 & 2001 & 2000 & 2001 & 2000 & 2001 & \\
\hline 134 & 8.4 & 11.3 & 308 & 352 & 719.4 & 723.3 & 37.8 \\
\hline 179 & 8.8 & 12.7 & 321 & 351 & 722.0 & 725.9 & 40.2 \\
\hline 224 & 9.0 & 14.2 & 321 & 368 & 718.1 & 733.6 & 43.7 \\
\hline 269 & 9.0 & 14.9 & 319 & 382 & 720.7 & 738.7 & 42.2 \\
\hline 314 & 8.9 & 14.9 & 325 & 384 & 720.7 & 737.4 & 41.6 \\
\hline LSD @ $p \leq 0.01$ & \multicolumn{2}{|c|}{ Columns $=0.3$} & & $\begin{array}{l}12 \\
14\end{array}$ & & $\begin{array}{l}4.4 \\
4.6\end{array}$ & 2.3 \\
\hline
\end{tabular}

\footnotetext{
${ }^{a}$ Means of four replications and four $\mathrm{K}$ fertility treatments $(0,45,90$, and $134 \mathrm{~kg} \mathrm{Kha}^{-1}$ ).

${ }^{b}$ Means of 2 years (2000 and 2001).
} 
solution will alleviate an $\mathrm{N}$ deficiency in plant tissue and allow sufficient levels of enzymes involved in photosynthesis and photosynthate translocation to be produced. Streeter and Barta (1984) stated that a maize plant is "programmed" to reproduce and when $\mathrm{N}$ levels are low, it will sacrifice older and noncritical tissue by remobilizing required $\mathrm{N}$ to reproductive tissue. They also reiterate findings of others that nutrient deficiencies do not have to produce visual symptoms to negatively impact biological and economic yield.

No significant differences in yield, kernel weight, grain bulk density, or HI were observed among $\mathrm{K}$ fertility treatments of this study. Neither were significant interactions for these variables observed between $\mathrm{N}$ fertility and $\mathrm{K}$ fertility levels or years in this experiment.

\section{Ear Leaf Observations}

Ear leaf dry weights per plant at R2 were not significantly different among years, $\mathrm{N}$ or $\mathrm{K}$ fertility treatments. Nitrogen concentrations in the ear leaves, however, were significantly less at $134 \mathrm{~kg} \mathrm{Nha}^{-1}$ than the higher $\mathrm{N}$ fertility levels (Table 2). The lower concentration also resulted in less total $\mathrm{N}$ in these ear leaves than was observed in higher $\mathrm{N}$ fertility levels (Table 3 ).

Results similar to those with $\mathrm{N}$ occurred with $[\mathrm{K}]$ in the ear leaves as $\mathrm{K}$ fertility increased (Tables 4 and 5). Lack of any additional $\mathrm{K}$ fertilizer resulted in $[\mathrm{K}]$ values in the ear leaves significantly $(p \leq 0.05)$ less than treatments receiving additional $\mathrm{K}$. No significant differences were observed in $[\mathrm{K}]$ of ear leaves among treatments receiving supplemental K fertilizer (Table 4). Significantly $(p \leq 0.05)$ less total $\mathrm{K}$ in ear leaves was observed at the $0 \mathrm{~kg} \mathrm{~K} \mathrm{ha}^{-1}$ treatment than those receiving supplemental $\mathrm{K}$ fertilizer (Table 5).

Increased $\mathrm{K}$ fertility resulted in a decline in both [Ca] and $[\mathrm{Mg}]$ of ear leaves (Table 4). However, only total $\mathrm{Mg}$ content of the ear leaf was significantly decreased as $\mathrm{K}$ fertility levels increased (Table 5). Calcium content was not significantly affected. Previous reports by Walker and Peck (1974 and 1975) showed negative correlations between plant $\mathrm{K}$ and plant $\mathrm{Mg}$ and between K fertility and leaf Mg levels. Walker and Raines (1988) later reported that $\mathrm{K}$ fertility had a negative effect upon leaf $\mathrm{Ca}$ in three of five maize cultivars and all cultivars with respect to leaf $\mathrm{Mg}$ levels. Cripps (1989) reported that increasing $\mathrm{K}$ fertilization rates on bermudagrass [Cynodon dactylon (L.) Pers.] increased plant $[\mathrm{K}]$ and decreased plant $[\mathrm{Ca}]$ and $[\mathrm{Mg}]$.

The $[\mathrm{Mn}],[\mathrm{Zn}]$, and $[\mathrm{Cu}]$ in ear leaves were positively affected by $\mathrm{N}$ fertility (Table 2). Concentrations of these micronutrients increased significantly $(p \leq 0.05)$ as $\mathrm{N}$ fertility rates increased. They are identified to have enzyme functions, usually as cofactors (Streeter and Barta 1984). Manganese is commonly associated with electron transport in PS II but is also involved in oxidation-reduction reactions, decarboxylation, and hydrolysis (Rains 1976). As $\mathrm{N}$ fertility levels increase, levels of $\mathrm{Mn}, \mathrm{Zn}$, and $\mathrm{Cu}$ 


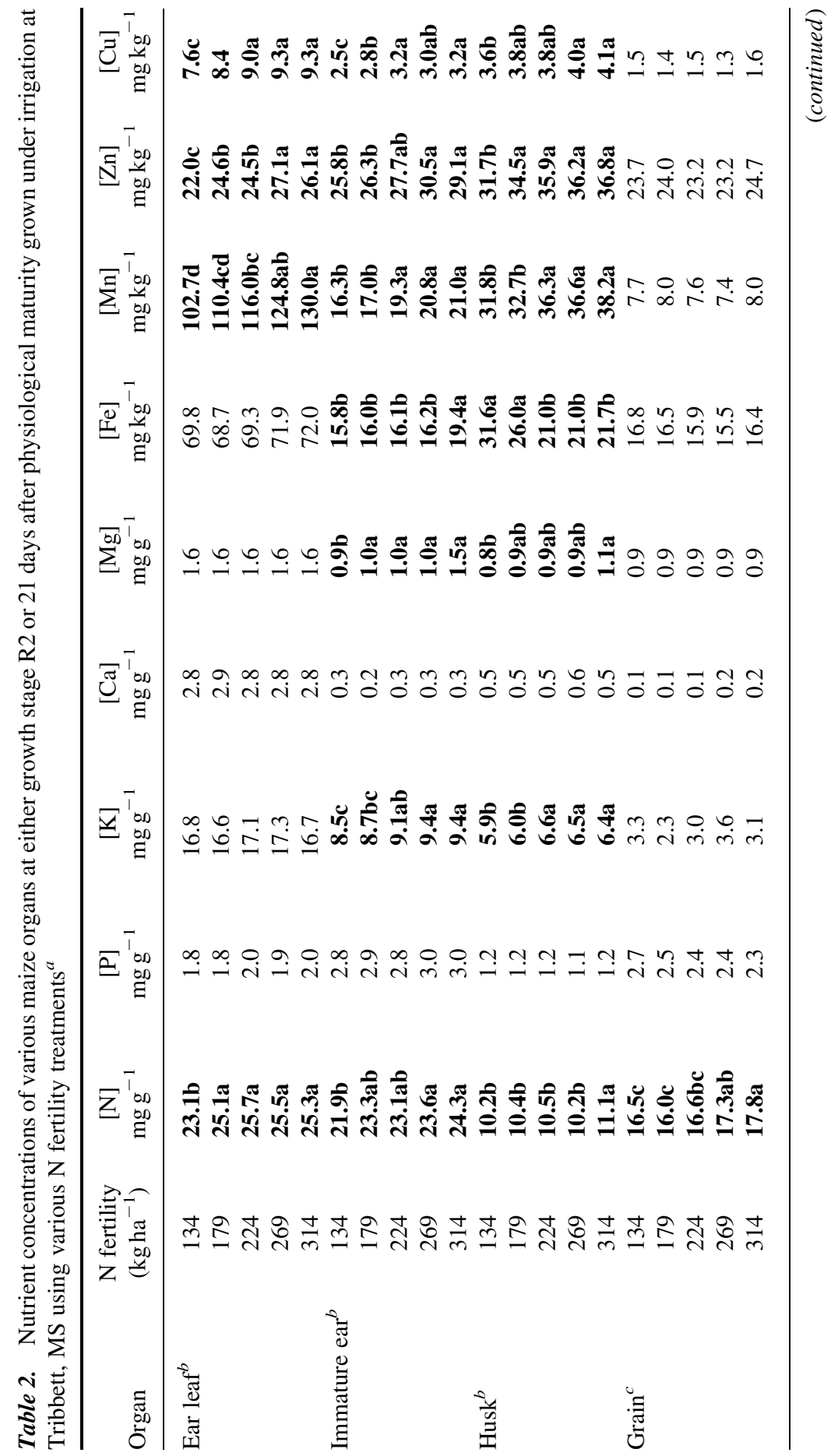




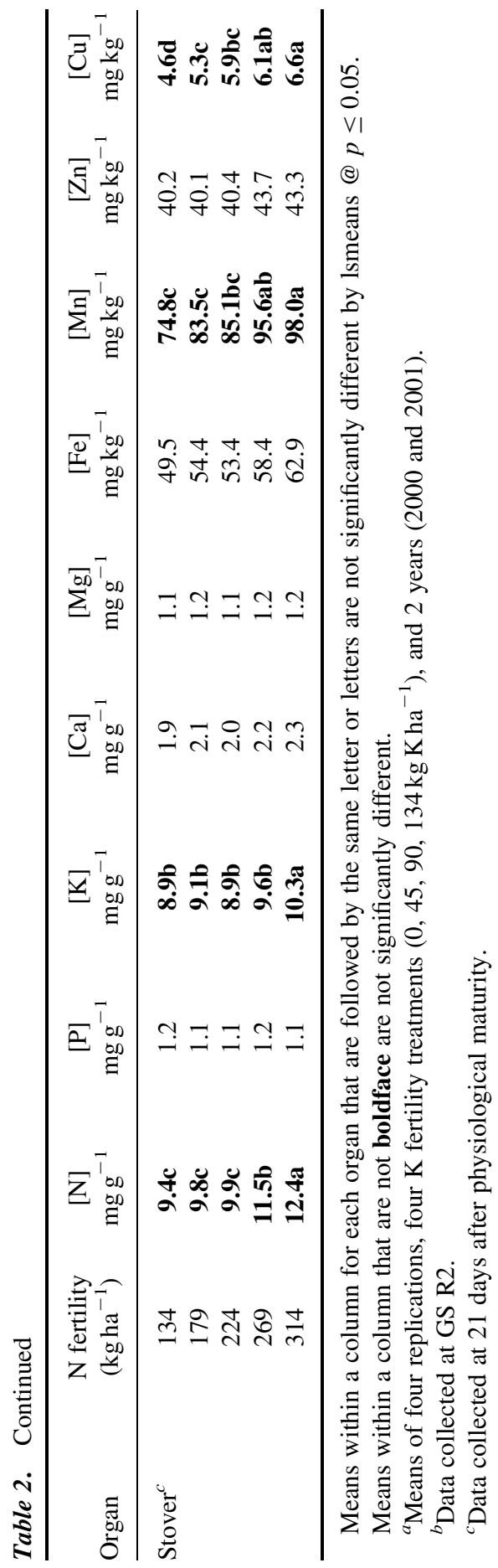




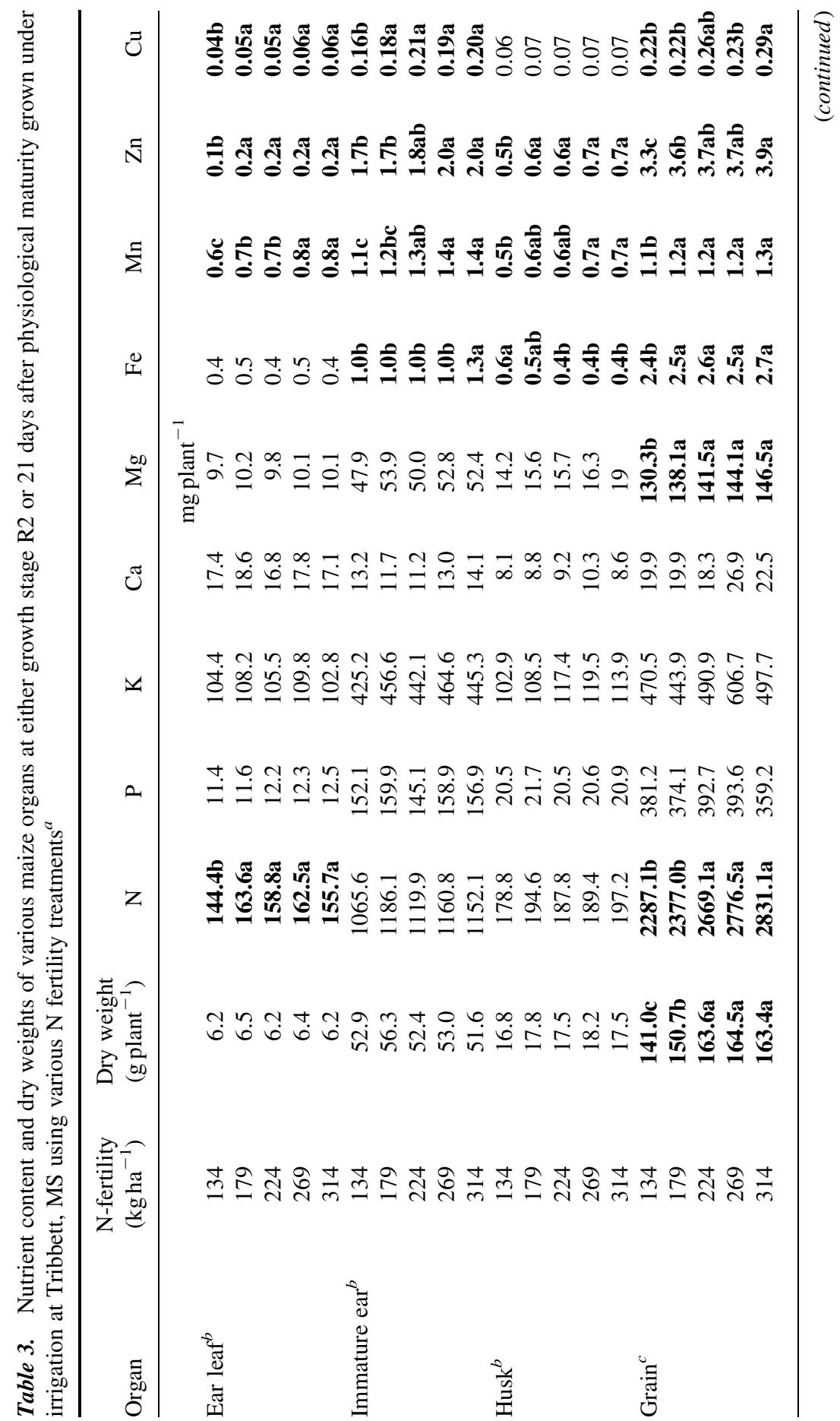




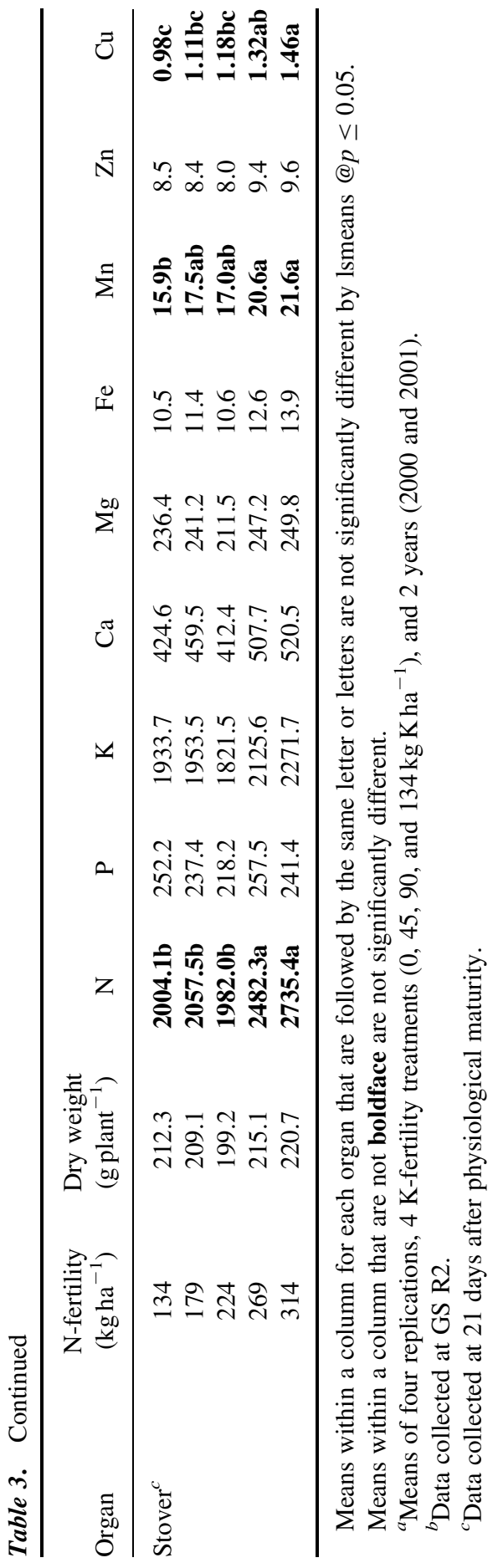




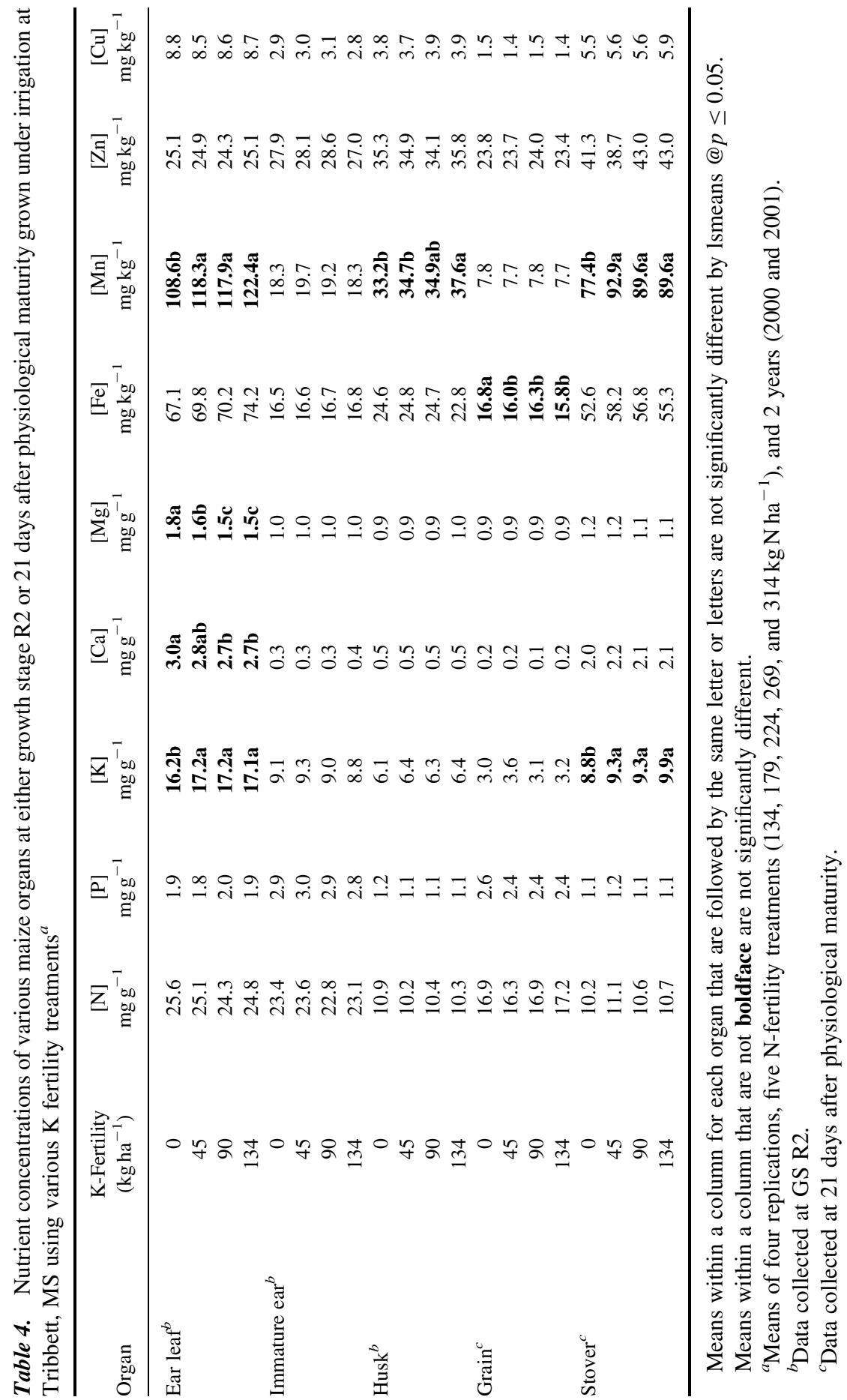




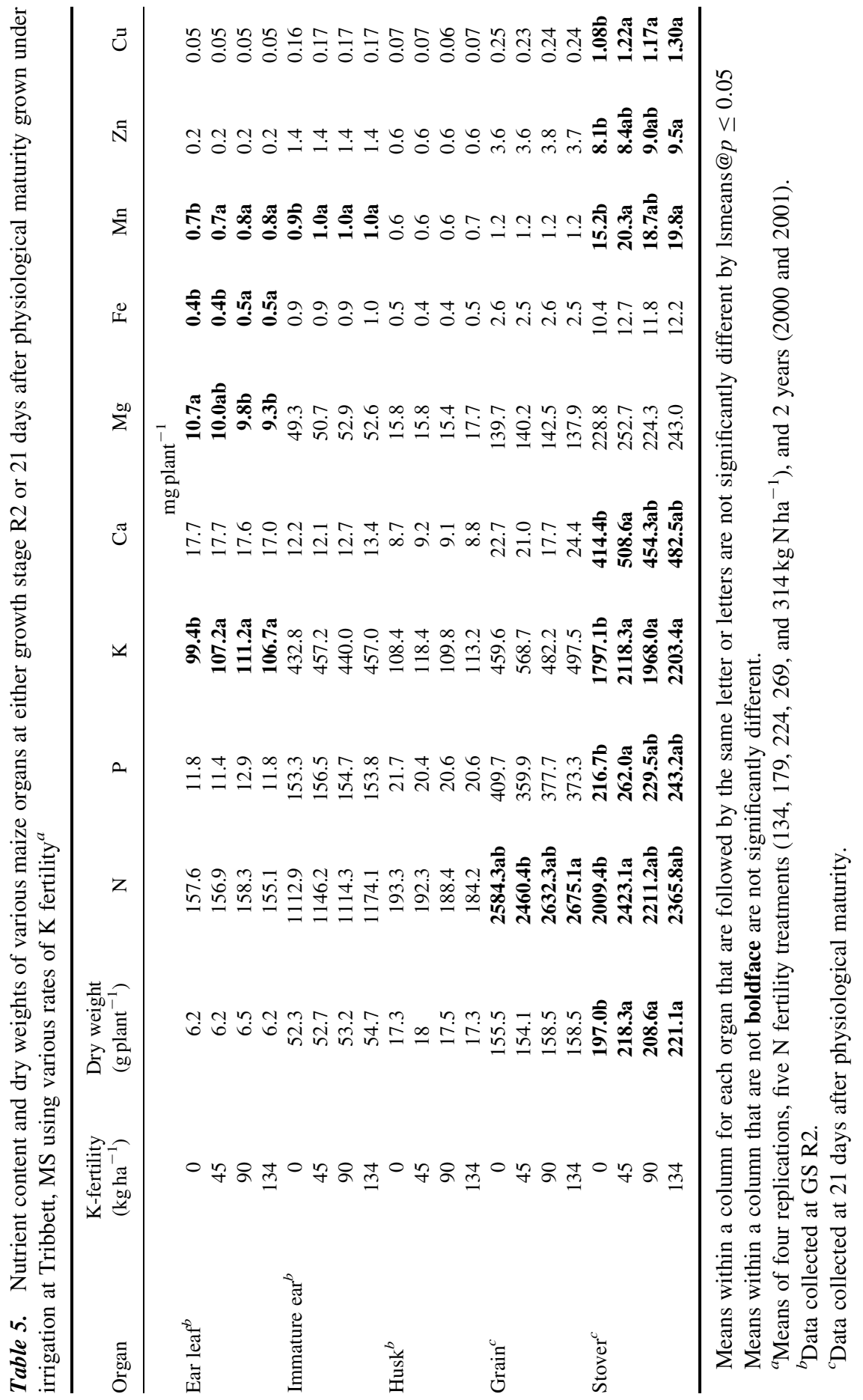


containing enzymes in the plant will likely increase and thus concentrations of these micronutrients.

The $[\mathrm{Mn}]$ in ear leaves was the only micronutrient evaluated that was affected by $\mathrm{K}$ fertility (Table 4). Manganese concentrations at the $0 \mathrm{~kg} \mathrm{Kha}^{-1}$ fertility rate were significantly $(p \leq 0.05)$ less than plants receiving additional $\mathrm{K}$ fertilizer. Both of these elements have important roles in production and translocation of photosynthate.

\section{Immature Ear Observations}

Immature ears collected in 2001 were more advanced in development than those collected in 2000 as determined by dry weights (73.4 g vs. $33.1 \mathrm{~g}$ ). Interactions involving year as a component, however, were not observed to be significant for nutrient concentrations. Concentrations of $\mathrm{N}, \mathrm{K}, \mathrm{Mg}, \mathrm{Fe}, \mathrm{Mn}, \mathrm{Zn}$, and $\mathrm{Cu}$ in developing ears significantly $(p \leq 0.05)$ increased as $\mathrm{N}$ fertility rates increased (Table 2). Developing maize ears are strong sinks of high metabolic activity. Potassium plays a major role in photosynthate translocation, whereas $\mathrm{Mg}, \mathrm{Fe}, \mathrm{Mn}, \mathrm{Zn}$, and $\mathrm{Cu}$ have important functions in enzyme activity (Streeter and Barta 1984). Higher $\mathrm{N}$ fertility rates that result in increased grain yields most likely do so by increasing quantities of enzymes responsible for photosynthate translocation to developing kernels. This in turn increases demand and thus concentrations of their metal cofactors. No significant differences were noted however, for either $[\mathrm{P}]$ or $[\mathrm{Ca}]$ in the developing ears.

Total content of $\mathrm{N}, \mathrm{P}, \mathrm{K}$, and $\mathrm{Ca}$ in the developing ear was significantly $(p \leq 0.05)$ greater in 2001 than 2000 (Table 6). This is expected because of differences in ear dry weights between the 2 years. The Year $\times \mathrm{N}$ fertility

Table 6. Total N, P, K, and Ca content of maize ears at growth stage R2 grown at Tribbett, MS in 2000 and 2001 with different levels of $\mathrm{N}$ and $\mathrm{K}$ fertility ${ }^{a}$

\begin{tabular}{lrr}
\hline & \multicolumn{2}{c}{ mg plant $^{-1}$} \\
\cline { 2 - 3 } Element & 2000 & 2001 \\
\hline $\mathrm{N}$ & 909.7 & 1364.1 \\
$\mathrm{P}$ & 94.5 & 214.6 \\
$\mathrm{~K}$ & 336.8 & 556.7 \\
$\mathrm{Ca}$ & 11.1 & 14.2 \\
\hline
\end{tabular}

${ }^{a}$ Means of four replications, five $\mathrm{N}$ fertility treatments (134, 179, 224, 269, and $\left.314 \mathrm{~kg} \mathrm{Nha}^{-1}\right)$, and four $\mathrm{K}$ fertility treatments $\left(0,45,90\right.$, and $\left.134 \mathrm{~kg} \mathrm{Kha}^{-1}\right)$. Means within a row are significantly different @ $p \leq 0.05$. 
rate interaction for total $\mathrm{N}$ content of the developing ear was statistically significant $(p \leq 0.01)$ (Table 7). No trend in total $\mathrm{N}$ content of the immature ears as related to $\mathrm{N}$ fertility was evident in 2000 , although total $\mathrm{N}$ content of immature ears at $314 \mathrm{~kg} \mathrm{Nha}^{-1}$ was significantly lower than at $179 \mathrm{~kg} \mathrm{Nha}^{-1}$. In 2001, total $\mathrm{N}$ content for $\mathrm{N}$ fertility rates of $179 \mathrm{~kg} \mathrm{Nha}^{-1}$ and above were significantly $(p \leq 0.01)$ greater than those of $134 \mathrm{~kg} \mathrm{Nha}^{-1}$.

\section{Husks Observations}

Information on developing maize husks is very limited. The organ's primary function is to protect silks during pollination and developing kernels from predation by insects, birds, and diseases. It also maintains a moist environment for actively growing cells of developing ears. These modified leaves, where exposed to sunlight, do develop chlorophyll and carry on photosynthesis. However, much of this tissue is tightly covered by the outermost leaves and exposed to very diffuse amounts or no sunlight at all and, thus, have little or no chlorophyll. The $[\mathrm{N}]$ of husks in this experiment was greatest in plants grown on plots fertilized with $314 \mathrm{~kg} \mathrm{Nha}^{-1}$, whereas no significant differences in $[\mathrm{N}]$ were observed at any of the other $\mathrm{N}$ fertility levels (Table 2). Total $\mathrm{N}$ content of the husks were unaffected by $\mathrm{N}$ fertility (Table 3).

The $[\mathrm{K}],[\mathrm{Mg}],[\mathrm{Mn}],[\mathrm{Zn}]$, and $[\mathrm{Cu}]$ in the husks tended to increase with increases in $\mathrm{N}$ fertility, but [Fe] declined (Table 2). Similar trends were observed for total contents of $\mathrm{Fe}, \mathrm{Mn}$, and $\mathrm{Zn}$ in the husks. Increases in concentrations and contents for the elements noted are likely due to their association with enzymes responsible for translocation of photosynthate to developing ears. As $\mathrm{N}$ availability increased because of fertilization,

Table 7. Total nitrogen content of maize ears at growth stage $\mathrm{R} 2$ grown with different rates of $\mathrm{N}$ fertility at Tribbett, MS in 2000 and $2001^{a}$

\begin{tabular}{lcl}
\hline \multirow{2}{*}{$\begin{array}{l}\text { N fertility } \\
\left(\mathrm{kg} \mathrm{ha}^{-1}\right)\end{array}$} & \multicolumn{2}{c}{$\mathrm{mg} \mathrm{N}$ plant $^{-1}$} \\
\cline { 2 - 3 } 134 & 2000 & 2001 \\
179 & 948.8 & 1182.3 \\
224 & 1019.2 & 1353 \\
269 & 863.5 & 1376 \\
314 & 864.7 & 1456.8 \\
\hline
\end{tabular}

${ }^{a}$ Means of four replications and four K-fertility treatments $\left(0,45,90\right.$, and $\left.134 \mathrm{~kg} \mathrm{Kha}^{-1}\right)$. LSD @ $p \leq 0.01$ columns $=156$; rows $=186$. 
enzymes involved in transporting photosynthate would increase in concentration and thus an increase in their metal cofactors would be required. The decline in both $[\mathrm{Fe}]$ and total content of $\mathrm{Fe}$ in the husks with increases in $\mathrm{N}$ fertility cannot currently be explained. It is known that high $\mathrm{pH}, \mathrm{Ca}, \mathrm{NO}_{3}$, and phosphates can suppress Fe uptake. Iron is also highly immobile in the plant and not translocated from one tissue to another (Gardner et al. 1985). Heavy flow of nutrients to developing ears may be responsible for observed declines in Fe in husks by interfering with its uptake by that organ.

\section{Grain Observations}

Grain yield plant ${ }^{-1}$ was significantly $(p \leq 0.05)$ greater for $\mathrm{N}$ fertility levels of $224 \mathrm{~kg} \mathrm{~N} \mathrm{ha}^{-1}$ and above than for the two lower levels (Table 3). Increased $\mathrm{N}$ fertility increased $[\mathrm{N}]$ in mature grain (Table 2). This increase combined with the increase in grain yield plant ${ }^{-1}$ due to increased $\mathrm{N}$ fertility resulted in significantly more total $\mathrm{N}$ plant ${ }^{-1}$ in the grain at $\mathrm{N}$ fertility levels above $179 \mathrm{~kg} \mathrm{~N} \mathrm{ha}^{-1}$ (Table 3). Kurtz and Smith (1966) reported that increases in $\mathrm{N}$ fertility generally increased protein content in maize grain, which will be the primary form of $\mathrm{N}$ found in the tissue. However, they also stated that such increases can result in relative reductions in some essential amino acids and are highly dependent on environmental and genetic factors that influence the amount of any observed protein increase. Research on wheat (Triticum aestivum L.) and rye (Secale cereale L.) also demonstrated increased grain protein levels with increased N fertility (Fowler 1989). Concentrations of $\mathrm{P}, \mathrm{K}$, and $\mathrm{Ca}$ in grain as well as their total content per plant in grain were unaffected by both $\mathrm{N}$ and $\mathrm{K}$ fertility levels.

Although $[\mathrm{Mg}],[\mathrm{Fe}],[\mathrm{Mn}],[\mathrm{Zn}]$, and $[\mathrm{Cu}]$ in grain were not significantly different among $\mathrm{N}$ fertility treatments, their total contents significantly $(p \leq 0.05)$ increased to varying degrees as $\mathrm{N}$ fertility rates increased. Magnesium content at $\mathrm{N}$ fertility rates of $179 \mathrm{~kg} \mathrm{Nha}^{-1}$ and above were greater than those at $134 \mathrm{~kg} \mathrm{Nha}^{-1}$ rate. The same was true for both $\mathrm{Fe}$ and Mn contents. Zinc content exhibited a positive and significant $(p \leq 0.01)$ linear correlation with $\mathrm{N}$ fertility rates $(\mathrm{r}=0.061)$. Copper contents in grain tended to slightly increase with increasing $\mathrm{N}$ fertility rates. The lack of increase in concentrations of these elements in grain indicates that their observed increase in total contents are due to increases in grain weight that occurred as $\mathrm{N}$ fertility rates increased.

Increasing levels of $\mathrm{K}$ fertility had no significant effect on nutrient concentrations in grain except for Fe. Iron concentrations were significantly $(p \leq 0.05)$ greater in maize grain that received no supplemental $\mathrm{K}$ fertilizer compared with those plots that did (Table 4). However, differences were very small and likely had no negative impact on yield.

Significant $(p \leq 0.05)$ differences in $\mathrm{N}$ content in grain were observed among the $\mathrm{K}$ fertility treatments (Table 5 ). However, no trend among these 
differences was evident. Total contents of no other element in the grain were found to be significantly different among the $\mathrm{K}$ fertility treatments.

\section{Stover Observations}

Total dry weight of stover plant ${ }^{-1}$ was unaffected by $\mathrm{N}$ fertility (Table 3 ). Nitrogen concentrations in stover, however, were significantly $(p \leq 0.05)$ greater at $\mathrm{N}$ fertility levels of $269 \mathrm{~kg} \mathrm{Nha}^{-1}$ than at lower levels of $\mathrm{N}$ fertility (Table 2). The $[\mathrm{N}]$ of stover at $314 \mathrm{~kg} \mathrm{Nha}^{-1}$ was significantly $(p \leq 0.05)$ greater than all other treatments. Total $\mathrm{N}$ content of stover was significantly $(p \leq 0.05)$ greater at 269 and $314 \mathrm{~kg} \mathrm{Nha}^{-1}$ than the three lower $\mathrm{N}$ fertility levels (Table 3). Dry matter accumulation in stover is virtually completed by growth stage R2 and makes up about $60 \%$ of the plant's total dry weight (Ritchie et al. 1997). Nitrogen in vegetative organs of a plant is largely a component of functional rather than structural compounds and is readily translocated to younger more metabolically active tissue such as developing kernels as a plant matures (Gardner et al. 1985). Potassium concentrations in stover were significantly $(p \leq 0.05)$ greater at $314 \mathrm{~kg} \mathrm{Nha}^{-1}$ fertility level than lower levels of $\mathrm{N}$ fertility (Table 4). However, total content of $\mathrm{K}$ in the stover was unaffected by varying $\mathrm{N}$ fertility levels.

Total dry weight of stover plant ${ }^{-1}$ was greater for $\mathrm{K}$ fertility treatments receiving additional $\mathrm{K}$ fertilizer than the $0 \mathrm{~kg} \mathrm{Kha}^{-1}$ treatment (Table 5). Similar observations were made regarding $[\mathrm{K}]$ and $[\mathrm{Mn}]$ in the stover. Total contents of all elements evaluated, except $\mathrm{Mg}$ and $\mathrm{Fe}$, differed significantly $(p \leq 0.05)$ among $\mathrm{K}$ fertility treatments (Table 5). Total contents of all affected elements were least at the $0 \mathrm{~kg} \mathrm{Kha}^{-1}$ treatment and generally greatest at the $134 \mathrm{~kg} \mathrm{Kha}^{-1}$ treatment. With exception of $\mathrm{K}$ and $\mathrm{Mn}$, which had concentration levels that were significantly different, observed differences in content among remaining elements due to $\mathrm{K}$ fertility are most likely due to differences in resulting dry weights of stover.

\section{CONCLUSIONS}

Both $\mathrm{N}$ and $\mathrm{K}$ fertility treatments had no effect on $[\mathrm{P}]$ and $\mathrm{P}$ content except in stover, where a significant $(p \leq 0.05)$ increase in $\mathrm{P}$ content was observed with increasing levels of $\mathrm{K}$ fertility. This increase is significantly $(p \leq 0.05)$ correlated $\left(r^{2}=0.74\right)$ with observed increases in total dry weight of stover plant ${ }^{-1}$ that occurred and is not likely due to an increase in $\mathrm{P}$ uptake by the plant.

Yield and $[\mathrm{N}]$ of grain (Tables 1 and 2), among $\mathrm{N}$ fertility treatments used in this study, indicates a range of $139-265 \mathrm{~kg} \mathrm{Nha}^{-1}$ was permanently removed from the soil by harvesting and marketing. Using current $\mathrm{N}$ fertility recommendations for maize grain production in Mississippi and the range of yields in this study, $\mathrm{N}$ fertilizer needed to acquire these yield goals 
would total $193-321 \mathrm{~kg} \mathrm{Nha}^{-1}$ (Larson and Oldham 2003). These values are greater than those reported by Barber and Olson (1968). Based on data from this study, assuming an average of $5000 \mathrm{mg} \mathrm{N}$ plant $^{-1}$ in the whole above ground part of a maize plant (Table 3), over $368 \mathrm{~kg} \mathrm{Nha}^{-1}$ will be contained in a maize population of 73,500 plants ha $^{-1}$. As much as half of that will be returned to the soil in stover. However, biological activity and $\mathrm{N}$ transformations continue to occur during winter fallow in a humid subtropical environment, which will lower soil $\mathrm{N}$ levels. Some maize growers in the Mississippi Delta burn crop residue after harvest to facilitate tillage and destroy overwintering insect habitat. This practice would likely lower soil $\mathrm{N}$ levels still further. These data suggest that $\mathrm{N}$ fertility recommendations for the Mississippi Delta may be low for yield goals above $10 \mathrm{Mg} \mathrm{ha}^{-1}$.

Potassium in this study showed no beneficial effects to yield. However, the importance of $\mathrm{K}$ in regulating water status of maize plants and their overall growth is well documented. These data show that maize crops in the Mississippi Delta do increase their overall uptake of $\mathrm{K}$ when additional $\mathrm{K}$ fertilizer is applied, but that rates above $45 \mathrm{~kg} \mathrm{Kha}^{-1}$ may not be economically beneficial to the maize. However, in the Mississippi Delta, most maize is grown in rotation with cotton, which has a high demand for $\mathrm{K}$ during the short fruiting period typical of some of early maturing cultivars (Kerby and Adams, 1985; Tupper et al., 1996). Potassium nutrition has also been strongly related to increased fiber quality and decreased incidence of verticillium wilt (Verticillium dahliae Kleb.) and other cotton diseases (Minton and Ebelhar, 1991). Such demands by succeeding cotton crops may justify high application rates of $\mathrm{K}$ to maize in an attempt of increase soil $\mathrm{K}$ levels.

\section{ACKNOWLEDGMENTS}

We thank Dr. Keith Crouse and the technical staff of the Mississippi State University Extension Service Soil Testing Laboratory for conducting the plant tissue analyses and Mr. Roderick Patterson and Mr. Roosevelt Johnson for their technical assistance.

Trade names are used in this publication solely for the purpose of providing specific information. Mention of a trade name, propriety product, or specific equipment does not constitute a guarantee or warranty by the USDA-ARS or Mississippi State University and does not imply approval of the named product to the exclusion of other similar products.

\section{REFERENCES}

AOAC (1975) Official Methods of Analysis of the Association of Official Analytical Chemists, 12th ed., Method 47.021; Association of Official Analytical Chemist: Washington, D.C. 
Barber, S.A. (1976) Efficient fertilizer use. In Agronomic Research for Food; Patterson, F.L., ed.; Special Publication 26; American Society of Agronomy: Wisconsin, Madison, 13-29.

Barber, S.A. and Olson, R.A. (1968) Fertilizer use on corn. In Changing Patterns in Fertilizer Use; Nelson, L.B., ed.; Soil Science Society of America: Wisconsin, Madison, 163-188.

Cripps, R.W. (1989) Effects of potassium and lime applied for coastal bermudagrass production on sandy soil. Soil Science Society of America Journal, 53: 127-132.

Duvick, D.N. and Cassman, K.G. (1999) Post-green revolution trends in yield potential of temperate maize in the north-central United States. Crop Science, 39: $1622-1630$.

Fowler, D.B. (1989) Nitrogen fertilization of no-till winter wheat and rye. II. Influence on grain protein. Agronomy Journal, 81: 72-77.

Gardner, F.P., Pearce, R.B., and Mitchell, R.L. (1985) Physiology of Crop Plants; Iowa State University Press.: Ames, Iowa, 98-131.

Grissom, P. and Spurgeon, W.I. (1961) Fertility practices for cotton and corn in the Yazoo-Mississippi Delta, Agricultural Experiment Station Bulletin 614. Mississippi State University: Mississippi State, Mississippi.

Hageman, R.H. (1979) Integration of nitrogen assimilation in relation to yield. In Nitrogen Assimilation of Plants; Hewitt, E.J. and Cuttings, C.V., eds.; Academic Press.: New York, 591-611.

Kerby, T.A. and Adams, F. (1985) Potassium nutrition of cotton. In Potassium in Agriculture; Munson, R.D., ed.ASA, CSSA, and SSSA: Wisconsin, Madison, 845-8860.

Kurtz, L.T. and Smith, G.E. (1966) Nitrogen fertility requirements. In Advances in Corn Production; Pierre, W.H., Aldrich, S.A., and Martin, W.P., eds.; The Iowa State University Press: Ames, Iowa, 195-235.

Larson, E. and Oldham, L. (2003) Corn fertilization. MSUcares. Info. Sheet. 864. Ext. Ser. Miss. State Univ. [Online]. Available at http://msucares.com/pubs/infosheets/ is864.htm (verified 21, March 2003).

McIntosh, M.S. (1983) Analysis of combined experiments. Agronomy Journal, 75: $153-155$.

Minton, E.B. and Ebelhar, M.W. (1991) Potassium and aldicarb-disulfoton effects on verticillium wilt, yield, and quality of cotton. Crop Science, 31: 209-212.

NASS-USDA (National Agricultural Statistics). (2001) Grain crops national and state data. [Online]. Available at http://www.nass.usda.gov:81/ipedb/(verified 21, March 2003).

Rains, D.W. (1976) Mineral metabolism. In Plant Biochemistry, 3rd Ed.; Bonner, J. and Varner, J., eds.; Academic Press: New York, 561-597.

Rasmusson, D.C. and Gengenbach, B.G. (1984) Genetics and use of physiological variability in crop breeding. In Physiological Basis of Crop Growth and Development; Tesar, M.B., ed. ASA, CSSA: Wisconsin, Madison, 291-320.

Ritchie, S.W., Hanway, J.J., and Benson, G.O. (1997) How a Corn Plant Develops; Iowa State University of Science and Technology, Cooperative Extension Service: Ames, Iowa, Special report No. 48.

SAS Institute. (2001) SAS User's Guide: Statistics; Version 6.1. SAS Institute: Cary, NC.

Steckel, J.E. and Flannery, R.L. (1971) Simultaneous determinations of phosphorus, potassium, calcium, and magnesium in wet ash digestion solutions of plant tissue by autoanalyzer. In Instrument Methods for Analysis of Soils and Plant Tissue; Soil Science Society of America: Wisconsin, Madison, 83-95. 
Streeter, J.G. and Barta, A.L. (1984) Nitrogen and minerals. In Physiological Basis of Crop Growth and Development; Tesar, M.B., ed.; American Society of Agronomy, Crop Science Society of America: Wisconsin, Madison, 175-200.

Tisdale, S.L. and Nelson, W.L. (1975) Soil Fertility and Fertilizers, 3rd ed.; Macmillan Publishing Co., Inc.: New York, 311.

Tupper, G.R., Calhoun, D.S., and Ebelhar, M.W. (1996) Sensitivity of early-maturing varieties to potassium deficiency. In Proceedings of 1996 Beltwide Cotton Production Research Conference, National Cotton Council of America: Memphis, Tennesee, 625-628.

Walker, W.M. and Peck, T.R. (1974) Relationship between corn yield and plant nutrient content. Agronomy Journal, 66: 253-256.

Walker, W.M. and Peck, T.R. (1975) Effect of potassium upon the magnesium status of the corn plant. Communications in Soil Science and Plant Analysis, 6: 189-194.

Walker, W.M. and Raines, G.A. (1988) Effects of corn cultivar, phosphorus and potassium on yield and chemical composition. Journal of Plant Nutrition, 11: $1715-1726$. 